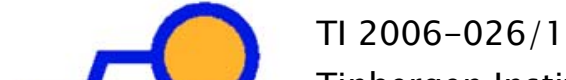

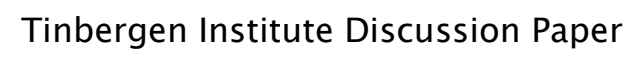 \\ When the Quality of a Nation triggers Emigration
}

Hendrik P. van Dalen ${ }^{1,2}$

Kène Henkens ${ }^{7}$

${ }^{7}$ Netherlands Interdisciplinary Demographic Institute (NIDI);

2 Department of Economics, Erasmus University Rotterdam, Tinbergen Institute, and ECRI. 


\section{Tinbergen Institute}

The Tinbergen Institute is the institute for economic research of the Erasmus Universiteit Rotterdam, Universiteit van Amsterdam, and Vrije Universiteit Amsterdam.

Tinbergen Institute Amsterdam

Roetersstraat 31

1018 WB Amsterdam

The Netherlands

Tel.: $\quad+31(0) 205513500$

Fax: $\quad+31(0) 205513555$

Tinbergen Institute Rotterdam

Burg. Oudlaan 50

3062 PA Rotterdam

The Netherlands

Tel.: $\quad+31(0) 104088900$

Fax: $\quad+31(0) 104089031$

Please send questions and/or remarks of nonscientific nature to driessen@tinbergen.nl.

Most TI discussion papers can be downloaded at http://www.tinbergen.nl. 


\title{
When the Quality of a Nation Triggers Emigration*
}

\author{
Hendrik P. van Dalen ${ }^{1,2}$ and Kène Henkens ${ }^{1}$ \\ ${ }^{1}$ Netherlands Interdisciplinary Demographic Institute (NIDI) \\ P.O. Box 11650 \\ NL - 2502 AR The Hague \\ The Netherlands \\ ${ }^{2}$ Erasmus University Rotterdam \\ Department of Economics, ECRI and Tinbergen Institute \\ P.O. Box 1738 \\ NL-3000 DR Rotterdam \\ The Netherlands
}

March 8, 2006

Corresponding author:

H.P. van Dalen, NIDI, P.O. Box 11650, NL-2502 AR, The Hague, The Netherlands, Tel: +3170 3565237; email: dalen@nidi.nl

JEL classification: F22, H4, J24, J61

Keywords: emigration, population pressure, intentions, public goods

\begin{abstract}
:
Why do people leave high-income countries with extensive welfare states? This article will examine what underlies the emigration intentions of native-born inhabitants of one industrialized country in particular: the Netherlands. To understand emigration from high-income countries we focus not only on factors that refer to individual characteristics, but also on the perception of the quality of the public domain, which involves institutions (social security, educational system, law and order) as well as the 'public goods' these institutions produce: social protection, safety, environmental quality, education, etc. Based on data about the emigration intentions of the Dutch population collected during the years 2004-2005 we conclude that besides traditional characteristics of potential emigrants - young, single, male, having a network in the country of destination, higher educated, seeking new sensations - modern-day emigrants are motivated not so much by private circumstances but by a longing for a better public domain. In particular, emigrants are in search of a better quality of life as approximated by the presence of nature, space, silence, and a less populated country. To gauge the effect of the quality of the public domain, a counterfactual scenario is offered, which suggests that a perception of severe neglect of the public domain substantially increases the pressure to emigrate. Under this scenario, approximately 20 percent of the Dutch population would express an intention to emigrate. Compared with the level of emigration intentions measured today, this represents an increase by a factor of 5 .
\end{abstract}

* In constructing the database we gratefully acknowledge the assistance provided by Susan ter Bekke. Comments by Douglas Hershey are gratefully acknowledged. 


\section{Introduction}

Migration is the main driving force of population growth in industrialized countries. In 1980, for instance, net migration accounted for 27 percent of the total population increase in the European Union, compared with 80 percent in 2004 (Eurostat, 2005). The case is less persuasive for the United States, where natural population increase is the main factor. Still, the share of net migration in the US population increase for the year 2004 was substantial, at 37 percent. This stylized fact of the demography of high-income countries is acknowledged and registered at macro level. What drives the separate immigration and emigration flows remains a difficult, yet important topic for scholars and policy makers alike. The consequences of unbalanced migration flows can be substantial for both source and destination countries. Many industrialized countries face an inflow of relatively low skilled immigrants (Boeri et al. 2002), and the outflow of native talent may to lead to a brain drain. Recently, Florida refueled the brain drain debate in his book The Flight of the Creative Class (2005) by noting how the United States is losing its edge in attracting and fostering creative talent, thereby endangering its track record in economic growth. Florida analyzes the position of the United States in the race for creativity and attributes its lagging performance, in part, to the country's increasingly restrictive policy regarding foreign workers. Although his messages sound familiar and have been stated somewhat differently in other 'doomsday books', the feared flight of its most talented people illustrates how emigration adds to the worries of a technologically advanced country. Unfortunately, emigration from industrialized countries has not been extensively examined, even though the consequences of emigration for these countries can be real and costly (cf. DeVoretz and Iturralde, 2001). Understanding what drives people out of their home countries or what motivates them to move to distant destinations is therefore of prime importance.

This article will examine the emigration intentions of the native-born inhabitants of an industrialized country, namely the Netherlands. The reason why immigrants come to the United States or Europe has been widely studied and the general driving force behind these migration flows is thought to be a higher living standard (cf. Hatton and Williamson, 2005). However, the puzzle posed by the emigration of the native-born from industrialized countries is far more complex. Why leave a country where the income level is high, public services are extensive and where the standard of living is the envy of immigrants from less developed countries? ${ }^{1}$ In short, are we overlooking facts or motives that do not feature in the textbook case of migration?

\footnotetext{
${ }^{1}$ This theme seems to be a recurrent one as in 1952 the demographer Kingsley Davis pointed out the irony of the Dutch fascination for emigration just after the Second World War: "Holland is the kind of country which normally, under present conditions, attracts rather than emits migrants.” (in: Petersen, 1952: xi)
} 
The economics of migration, initiated by Hicks (1932) and later developed by Sjaastad (1962) and Todaro (1969), stresses the fact that migration flows are driven primarily by differences in expected wages or skill prices. The research focus later shifted from the individual to the household as the appropriate decision-making unit. The ‘New Economics of Labor Migration’ as it was called by Stark and Bloom (1985) made a particularly important contribution to the individual decision-making framework by placing the migration decision in the household context. In this framework, networks and remittances play a crucial role in facilitating and maintaining migration flows. The macroeconomic empirics of migration confirm this as emigration flows from developing countries or countries in transition to developed countries are structural and substantial (Chiswick and Hatton, 2002, Clark et al., 2004, Hatton and Williamson, 2005).

In this article we shall take a broader view. In order to understand emigration from highincome countries we claim that the standard theory of migration, in which people are motivated by net wage differentials, is a good starting point, but it is not sufficient. We shall extend earlier research on emigration along two lines. First of all, we will pay attention to individual characteristics that are thought to underlie the economic, social and psychological net benefits of emigration. Besides the traditional forces in which migration is viewed as a decision influenced by the human capital stock of individuals, we include the forces exerted by social networks, and address the effects of personality traits on the likelihood of emigration, as suggested by psychologists (Boneva and Frieze, 2001 and Berry, 2001) and sociologists (De Jong and Fawcett, 1981, De Jong, 2000). The importance of these individual characteristics has been stressed in the past by scholars from different disciplines but they have never been examined in a single model.

Second, to understand emigration from high-income countries we shall focus not only on factors that refer to individual characteristics, but also on the perceived quality of the public domain in the source country. The general consensus among researchers is that the private domain is of prime importance in understanding international migration, but - as we will argue - the public domain may well be of substantial importance too. Several studies have focused on explaining emigration from highly developed countries, ${ }^{2}$ but none of the studies examines the public and private domains of life. Evaluating the quality of the public domain involves both the institutions (social security, educational system, law and order) and the 'public goods' these institutions produce: social protection, safety, environmental quality, education, integration, etc.

\footnotetext{
${ }^{2}$ The following studies have been carried out in the recent past: Burda et al. (1998) and Pfaff and Kim (2003) for East Germany; Hatton (2004) for the UK; Becker, Ichino and Peri (2003) for Italy; Pedersen, Røed, and Schröder (2003) for Scandinavian countries; Epstein and Gang (2004) for Hungary; De Voretz and Iturralde (1999) and Iqbal (2000) for Canada; Hugo, Rudd and Harris (2001) for Australia; Woodrow-Lafield (1996) and Borjas and Bradberg (1996) for the United States; Abrams et al. (2001) and Lam (2000) for Hong Kong.
} 
It would be somewhat presumptuous to claim that we are the first to suggest that the quality of public goods is a driving force for migration. Tiebout (1956) was as one of the first to argue that if a sufficient number of communities exist to accommodate the different type of preferences, individuals will organize themselves into communities that provide the public goods they want. This so-called Tiebout theorem was thought to be applicable to local public goods only and what we propose is that in a globalizing world in which citizens are highly mobile, it would also be useful in explaining international migration. The quality of the public domain - the quality of the environment, systems of law and order and social security - refers to issues that concern many European and American citizens and politicians. The institutions that govern the production of public goods and services face growing tensions due to demographic changes, globalization and related policy reforms.

For this study, emigration intention data were collected for the Netherlands. The majority of empirical research is based on a sample of immigrants in receiving countries (cf. Borjas, 1987, 1991). The problem of these post-move studies is that the validity is threatened by emigrant selection and migrant recall bias. In order to discover the roots of selection one should start in the source country and not in the host country, when selection has already taken place. As pointed out by Boneva and Frieze (2001: 483): “By studying actual immigrants, one is not able to separate clearly the effects of migration opportunities from the underlying desires to immigrate.” In addition, psychological research carried out in this field is based on convenience samples (Abrams et al., 1999; Boneva et al., 1998; Frieze et al., 2004), which do not provide a nationally representative picture. We collected data among a nation-wide sample of Dutch nationals to study the pressures to emigrate. In addition to this sample, we also used a targeted sample of potential emigrants as the number of potential emigrants was expected to be too low in a national representative sample.

The set-up of this article is as follows. First, we will review some of the most salient aspects of Dutch emigration history to provide a broader context for the extraordinary nature of today's upsurge in emigration. Next, we will provide the theoretical background in section 3. In section 4, we will describe data, measures of concepts and statistical methodology. Section 5 presents the results of the empirical analyses of the evaluation of public goods and their impact on intentions to migrate. In Section 6 we will make some concluding remarks and put the results in perspective.

\section{Dutch emigration history}

Like most European countries, the Netherlands has a long history of emigration. The Dutch emigration waves moved more or less in sync with the European migration waves of the nineteenth and twentieth centuries. The most significant periods of large-scale emigration occurred during the nineteenth 
century (1840s, 1860s and 1880s), the early 1900s and the years following the Second World War (Swierenga, 2000). What makes the post Second World War period stand out from other waves is the strong focus on an active emigration policy. During some years in the 1950s, the Dutch official government emigration target was 60,000 people a year. ${ }^{3}$ The main impetus to encouraging people to leave was the belief that the Netherlands was overcrowded and the prospect of long-lasting unemployment. The following statements give the reader a flavor of how sentiments changed after the war. In October 194634 percent of the Dutch answered affirmatively to the question 'Do you think it will be more difficult to find work two years from now?' About two years later, in March 1949, the Dutch were pessimistic about their future - despite strong economic growth - as 84 percent replied 'yes' to the same question. Emigration sentiments were also high at the time: in a European-wide survey held in April 1948 people were asked whether, if they had a choice, they would like to emigrate: 33 percent of the Dutch respondents said yes (Petersen, 1952: 10). Only the British respondents outranked the Dutch in terms of emigration sentiment: 42 percent of the British opted for emigration.

It is hard to pinpoint who influenced who at the time, but the pessimism was undoubtedly shared by the Dutch government. As prime minister Willem Drees said in an interview in 1950 "Some of our people should venture to seek a future in regions further afield than our own country, as they did in past centuries...” Efforts to reconstruct the Netherlands after the war met with more difficulties and hardships than expected during the euphoric years immediately following the Second World War. The most pressing problems felt by the population were overpopulation, the shortage of suitable housing and rising unemployment. To solve these problems, the Dutch government sought the answer in industrialization, reclaiming land from the sea, and emigration. The general policy approach to emigration was one of firm control until 1962, when conservative voices within parliament rejected an active emigration policy. Whereas the Netherlands' immigration policy was aimed at the temporary settlement of foreigners, its emigration policy was aimed at the permanent settlement of Dutch nationals in countries such as Canada, Australia and the United States. Knowledge about the consequences of migration and the rationality of migration policies was scant if not absent in the Netherlands. Sociologists and psychologists focused on types of migrants, and information about the labor and housing markets in prospective destination countries was weak if not false. The exception to the rule was the sociologist Petersen (1955) who criticized the prevailing emigration policy as being based on ill-founded preconceptions and values.

\footnotetext{
${ }^{3}$ An early econometric study by Isaac and Van den Beld (1953) concluded that the optimal net emigration rate should be in the range of 30,000 to 45,000 persons per year until 1961 .
} 
Some knowledge of migration history is needed to put today's emigration upsurge in perspective. A consistent time series covering post-war history is presented in Figure 1.

Figure 1: Emigration and immigration flows from and to the Netherlands, 1947-2005

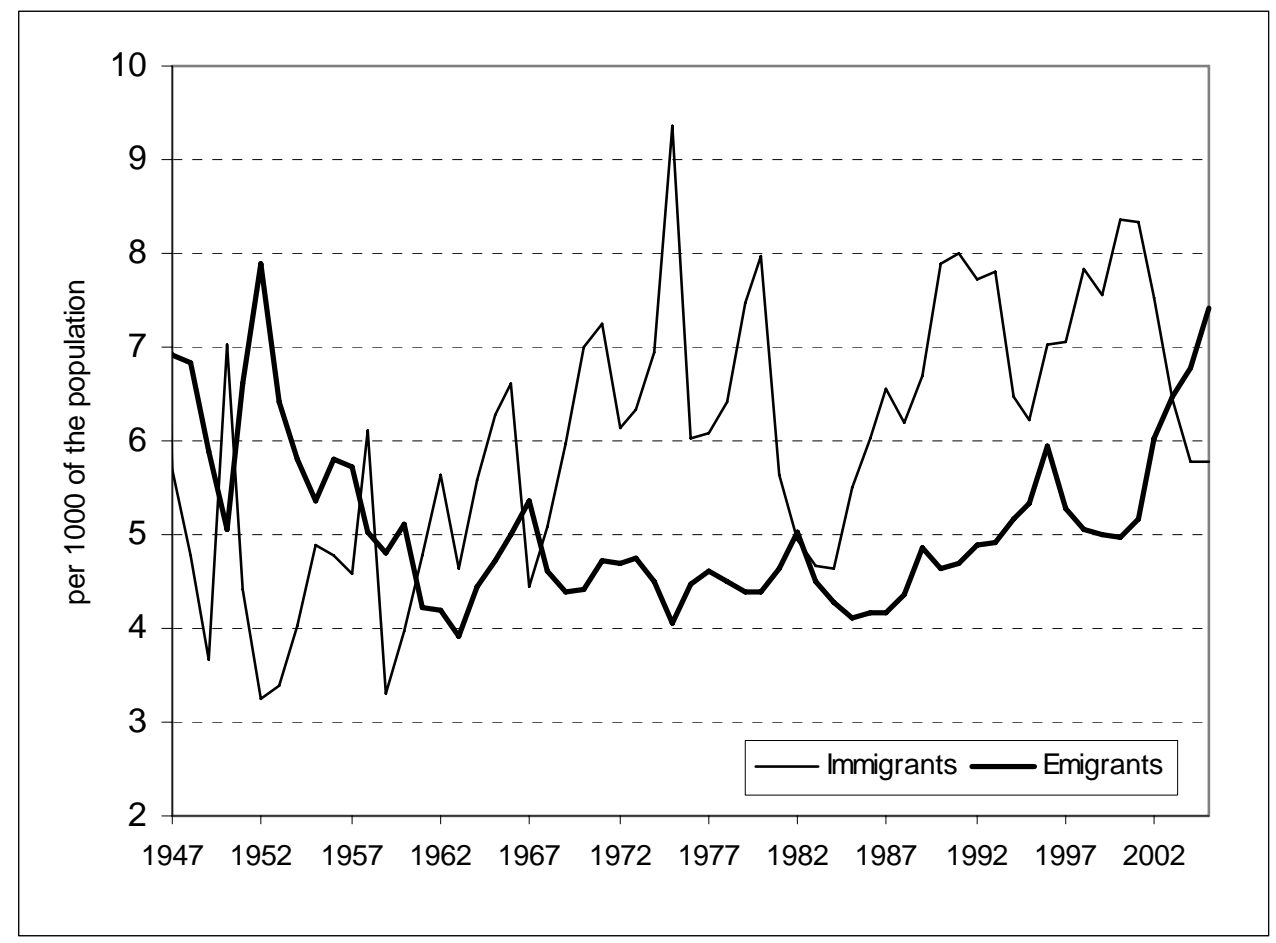

Source: $\underline{w w w . c b s . s t a t l i n e, ~ e m i g r a t i o n ~ i n c l u d e s ~ t h e ~ a d m i n i s t r a t i v e ~ c o r r e c t i o n s ~ r e g i s t e r e d ~ b y ~ m u n i c i p a l i t i e s . ~ N B: ~ s o m e o n e ~ i s ~}$ registered as an emigrant when he or she plans to reside abroad for more than eight months.

The emigration numbers of the past few years have been unrivalled in recent decades. In 1982 there was a small upward shift, suggesting that emigration was on the rise, but with hindsight it was only an incident in economic history and the prevailing consensus among policy makers and scholars was that the Netherlands has developed into an immigration country in the past three decades, albeit reluctantly. The shift in emigration is a phenomenon that emerged in the 1990s and really gained momentum after 2001. The sudden jump in emigration suggests that 'something' has changed in the Netherlands, and so far an abrupt reversal of the emigration trend is not in sight. ${ }^{4}$ We should, however, be cautious in

\footnotetext{
${ }^{4}$ For Dutch citizens - both native and migrants - three incidents marked the changing climate. The murders of the leading politician Pim Fortuyn (May 6, 2002) who made immigration and integration a major issue in his election campaign, the school teacher Hans van Wieren (January 13, 2004), and the film maker and public figure Theo van Gogh (November 3, 2004) received widespread attention and shook the confidence the Dutch had in the national government's ability to secure their safety. As the last two figures were murdered by Moroccan migrants, the murders symbolized for many the faltering integration of immigrants in Dutch society.
} 
sketching a picture in which the emigration flow as depicted in Figure 1 consists entirely of nativeborn Dutch. A considerable share of the total flow of emigrants leaving the Netherlands are return migrants, but this fact will not in any way reverse the general upward trend among native Dutch.

\section{Theoretical background}

To study emigration intentions, we have used theoretical insights on decision making that relate to the importance of the private as well as the public domains of life. The private domain refers to variables that can be controlled by individuals, or more broadly speaking households, and actions that benefit the individual or the household. The public domain of decision making refers to variables that are outside the direct control of individuals and relate to communities or societies at large. The problems of the public domain can only be dealt with by means of collective action.

\subsection{Private domain}

With the aid of basic migration theory we have distinguished three types of forces that provide an idea as to the factors that are important in triggering emigration: human capital, social networks and personality traits. We will expand on each of the arguments separately.

\section{Human capital}

The economics of migration is the starting point of our analysis as it provides a basis for understanding migration flows between countries. In a world with one type of worker and no adjustment or transaction costs of moving from one place to another the decision to emigrate is quite simple: as long as the expected wage in the preferred destination is higher than at home, emigration is a profitable option. Testing the proposition that wage differences are the driving force will prove difficult in a model that aims to distinguish migrants from non-migrants in the source country. There are, however, elements of human capital theory that offer predictions about the intensity to migrate that can be tested, like the role education, health and age play in triggering emigration. Starting with the most obvious element - education - we see that the large body of economic migration studies focus on the question whether migrants are favorably selected or not, where favorable selectivity refers to the tendency that the migration flow is disproportionately represented among the skilled or talented of a source country. Chiswick (1999) demonstrates with a simple model of migration how human capital, approximated by schooling or innate ability, increases the probability of migration. One of the reasons why favorable selectivity occurs is that higher-ability individuals can recoup the out-of-pocket costs of 
migration faster and they may also be more efficient in migrating and adapt more easily to the conditions of the country of destination (language, norms and rules). With regard to emigration from high-income countries we expect that the better educated will be more inclined to migrate because their human capital is more internationally transferable, yielding lower transaction costs tied to migration. Furthermore, the opportunities for the higher educated to work in an international labor market are greater, also because the international labor market offers more opportunities to specialize than the internal market. Although the arguments underlying the favorable selectivity of migrants sound persuasive, in the end it remains an empirical question whether the lesser skilled or the higher skilled are more likely to emigrate. ${ }^{5}$

The influence of people's health status on their emigration decisions follows in part the logic of the human capital model. Health is part of an individual's human capital, and potential migrants can recoup the investment costs of migration only if their health is good. In other words, poor health is associated with a weaker intention to emigrate than good health.

The role of age in migration decision making becomes clear by posing the question which moment in the life course is the best time to emigrate. The younger the migrant is, the longer the period of time the migrant needs to recoup the 'investment', i.e. moving the human capital from the source country to the destination country. Other factors might reinforce the age bias in migrating when the age-wage profile is steeper and when personal migration costs are age-related. In short, we would expect the desire to emigrate to be more evident among the young than among the old.

\section{Social networks}

Making migration decisions is not a purely individual decision and the influence of networks and pressures from family, friends or co-workers is bound to affect the decision to emigrate (as stressed by Stark and Bloom, 1985). The most obvious restriction influencing the migration decision is marital status. Marriage ties or the ties with children are assumed to be a restricting factor in the decision to migrate, raising migration costs and thereby changing the balance in favor of staying. Marriage dissolution radically changes the network structure in the household, giving the decision maker more leeway to make his or her own decisions. The effect of divorce may differ quite strongly from the effect of widowhood, however. Divorcees are single again, perhaps with children, but the incentive to start a new life away from the former partner may be even stronger than when they were single before marriage. Widowed people are also single again, but under these circumstances ties with families or

\footnotetext{
${ }^{5}$ Katz and Stark (1987, p. 722) present an example that produces a U-shaped pattern by skill level: only the lower level skills and higher level skills migrate. This pattern is in accordance with recent immigration developments in the US, which according to Schultz (1998) are dominated by the two extremes in the skill distribution.
} 
friends may become stronger to overcome grief and receive support, which reduces the incentive to migrate.

Whereas the social network in the home country may restrict migration, the availability of a social network of friends and family abroad is believed to increase the probability of emigration. The role played by migrant networks is well known (Massey, 1999). Networks not only provide information that may give a more accurate estimate of what potential migrants can earn abroad in real terms, but also, and more importantly, they offer services that lower the personal costs of migration and integration. Most studies therefore assume a relationship between the (adjustment) costs of migration and the size of the network. In other words, the larger the network of potential migrants, the more set they will be on emigrating. We will restrict ourselves to the theoretical prediction that the larger the number of emigrants in an individual's network, the stronger the intention to emigrate will be.

\section{Personality}

Leaving your home country can give rise to strong feelings of uncertainty, since living and working abroad may mean getting acquainted with a new culture or even adapting one's identity. Psychological characteristics are assumed to predict whether people will enter a new and unfamiliar situation as well as their affective reactions to a novel situation. In this article, we shall focus on two main personality traits that may contribute towards strong emigration intentions: sensation seeking and the level of selfefficacy. First, sensation seeking (Horvath and Zuckerman, 1993) can be of great importance to such daring moves as migration. Risk lovers or sensation seekers have a tendency to take more risks and perceive the world as less threatening. It is therefore likely that the more adventurous or risk loving a person is, the stronger the intention to emigrate will be.

The second personality trait that is deemed important in the decision to emigrate is selfefficacy. Self-efficacy, or the belief that one can effectively cope with a given situation, predicts whether people will enter a new and unfamiliar situation (Bandura, 1982; Sherer et. al., 1982). Selfefficacy predicts confidence in the ability to deal with changes and unfamiliar situations. Given that emigration is a new and uncertain experience, we assume that higher scores on self-efficacy will be associated with stronger intentions to emigrate.

\subsection{Public domain}

Several authors have demonstrated how the public domain - and public goods in particular - affect migration. The hypothesis that public goods trigger migration is essentially the theme put forward by 
Charles Tiebout (1956) for the competition between local communities in providing local public goods. In Tiebout's traditional set-up, free migration between localities can deliver the best possible situation in which communities supply the commodities and services individuals want and local governments produce these goods in an efficient manner. By decentralizing the public goods provision, people organize themselves in various communities that best fit their preferences. Needless to say, such an ideal outcome can only exist when everyone is mobile and there are sufficient communities to fit citizens’ preferences.

Another line of research is pursued by (economic) geographers who focus on local amenities as the driving force for regional migration and development, where the influence of amenities is manifested through wage or land rent compensation (Knapp and Graves, 1989). The focus on locationfixed amenities is largely on externalities of human action. The fact that people are attracted to cities because of the job opportunities there makes the agglomeration itself a source of positive externalities. And the fact that people move away from environmental hazards like waste sites or polluted cities is a case of migration in response to negative externalities. The driving force is a situation in which people neglect the effects - positive or negative - their actions can have on the welfare of others. The theory of amenities assumes that the mobility behavior of households or firms is also the mechanism by which location-fixed amenities are capitalized into labor or rent prices (Rosen, 1974). The effects of the public domain are effectively translated back into private domain values and the simple migration decision criterion on which neoclassical theory rests applies again.

In this article we argue that the public domain may perhaps affect relative prices, but that it is valued primarily for its own sake. In our view, the quality of the public domain depends on how citizens perceive the way in which (government) institutions function and the goods and services produced by these institutions. Public goods are traditionally defined as goods that are non-excludable - no one can be excluded from the use of the public good in question - and non-rivalrous - access by one user to the good does not in any way diminish other people's capacity to benefit from the good. Public goods should be interpreted broadly since 'goods' are, by definition, a response to a situation in which externalities are complex, i.e. most citizens benefit from the provision of a good, but every individual is tempted to free-ride on the efforts of others. For instance, silence is valued by most citizens but in order to 'produce' silence everyone has to act in accordance with the rules, certainly in densely populated areas or in areas where air, road or rail traffic is heavy. In some cases where externalities are straightforward, private transactions or negotiations can solve the problem (Coase, 1960), but once it affects the people of a city, region or nation and transaction costs tied to individual corrective action become excessively high, collective action may become necessary. Perceptions of the 
quality of the public domain are therefore a reflection of both the 'goods' and the governance institutions that try to correct externalities of individual action (cf. Kaul and Mendoza, 2004).

\section{Methods}

\subsection{Data}

To answer our research questions we collected data using a two-step approach. First, an emigration survey was carried out in the period October 2004-January 2005 using a targeted sampling method (Watters and Biernacki, 1989). This survey was geared toward over-sampling of potential emigrants to alleviate the problem that the number of potential emigrants was expected to be too low in national representative samples to produce adequate analyses. The visitors to an Expat fair, who saw themselves as potential emigrants ${ }^{6}$, were asked to participate in the survey. A total of 533 potential emigrants received a questionnaire, and 214 questionnaires were sent back (a response rate of 40 percent). The second step consisted of a nation-wide emigration survey, which was carried out in January 2005. The survey was conducted by the survey institute CentERdata of the University of Tilburg $^{7}$, which maintains a national representative panel of households in the Netherlands. We tested whether respondents with emigration intentions differed significantly in both samples in terms of the socio-demographic variables age, education, income and gender, as significant differences may point to biases in our sampling method. We found no statistically significant correlation. The two samples were combined to analyze emigration intentions in the Netherlands $(\mathrm{N}=1,489)$. The second sample was used to analyze expectations regarding the preferred destination countries, which were not posed in the nation-wide emigration survey. In this article, we will focus on the emigration of native-born individuals because they are, a priori, the ones who face the dilemma of leaving their home country.

\subsection{Measurement issues}

We used two dependent variables to examine what triggers emigration: one intention variable and one variable revealing preparatory behavior. The intention was measured by an ordered categorical variable representing the response to the question: Do you intend to emigrate in the near future? The

\footnotetext{
${ }^{6}$ The Expat fair was a meeting ground for "those who want to work, live, study, do business and settle abroad". Visitors were asked to indicate whether they considered themselves to be (1) expatriates; (2) potential emigrants; (3) interested in studying abroad; (4) human resource management/multinational; (5) interested in doing business abroad. We focused exclusively on the second category.

${ }^{7}$ For details, consult http://www.uvt.nl/centerdata/en/.
} 
responses comprised a five-category ranking of intentions: (1) no, certainly not; (2) no, probably not; (3) maybe; (4) yes, probably; and (5) yes, very probably.

\section{Box 1: Explanatory variables defined}

- Age, stated in years

- Gender, male $=0$ or reference category, female $=1$

- Marital status: (1) married ( = 0); (2) divorced; (3) widowed; (4) never married.

- Number of children

- Health status: How do you rate your health status in general? (1) very good; (2) reasonably good; (3) not good/not bad; (4) reasonably bad; (5) very bad.

- Educational level defined by the highest attained level: Low (lower vocational training, primary school = 0); Intermediate (high school; intermediate vocational training; High (university and higher vocational training).

- Employment status: (1) employee (= 0); (2) retired; (3) disabled or unemployed; (4) housewife; (5) student; (6) self-employed.

- Income level: What is your net household income? (1) less than $€ 2500(=0)$; (2) $€ 2500$ to $€ 4000$; (3) more than $€ 4000$.

- Network contacts: Do you know family members and friends who have emigrated? (1) No; (2) Yes, if so how many? ..... (persons)

- The scale variables Private living conditions, Welfare state institutions, Societal problems and Environmental quality are based on the following questions about home country characteristics. How do you rank the following aspects: (1) your housing; (2) your income; (3) your working conditions; (4) your social contacts; (5) the health care system; (6) social security system; (7) educational system; (8) system of law and order; (9) pension system; (10) the amount of nature and space; (11) the population density; (12) the level of silence; (13) the crime level; (14) the level of pollution; (15) the mentality of the people; and (16) the level of ethnic diversity. All dimensions are evaluated by five options (1) very positive; (2) positive; (3) neutral; (4) negative; (5) very negative.

- The scale variable Sensation seeking is derived from the responses to a set of Likert-type questions (cf. Zuckerman, 1971). The following items were included: (1) New and unexpected experiences give me the excitement I need in life; (2) When I have to work according to fixed rules, I easily get fed up with them; and (3) People or things that always stay the same, bore me. Respondents could answer on a five-item scale ranging from (1) totally agree to $(5)$ totally disagree (Cronbach's alpha $=0.64$ ).

- The variable Self-efficacy is based on three Likert-type items (cf. Bosscher and Smit, 1998): (1) When I make plans, I am convinced that I will succeed in carrying out these plans; (2) When I decide to do something, I firmly cling to that decision; and (3) When unexpected problems occur, I do not handle them well. Answer categories varied from (1) totally agree to (5) totally disagree. (Cronbach’s alpha $=0.61)$. 
The variable revealing preparatory behavior was based on three questions. We asked whether respondents (1) had visited the embassy for information about the country of destination; (2) had approached an emigration intermediary or consultant; or (3) had visited a meeting to inform future emigrants (answer categories: $0=$ no; 1 = yes). To indicate the extent to which respondents were involved in actual preparatory behavior, we summed the answers to the three questions into a scale ranging from $0=$ no preparatory behavior to $3=$ having performed three visits to prepare for emigration (Cronbach's alpha $=0.70)$. Box 1 presents the wording of the survey questions of all measures of the explanatory variables in this article, as well as their psychometric properties.

\subsection{Statistical methodology}

To establish the scales for the respondents' evaluation of their home country, analyses were carried out in two steps. And as we had no a priori information on which dimensions of the quality of a nation are clustered together, we first used a principal components analysis to identify the relationship among 16 different aspects of the respondents' opinions regarding the public and private domains of their home country (see Box 1), and subsequently examined whether this relationship could be expressed in terms of a number of separate dimensions by means of varimax rotation. Principal components analysis is a statistical technique that linearly transforms an original set of variables into a substantially smaller set of uncorrelated variables that represent most of the information in the original set of variables. Rotation results in variables loading primarily on one component and having either high or low loadings on a component, and hence in many instances brings about a simplification of the initial solution, where variables might have moderate loadings across a number of components (Dunteman, 1989). The simplicity of the rotated factor loading matrix makes interpretation easier. All analyses were also carried out using promax rotation, and this did not change our results.

The intention of individuals to emigrate and their involvement in preparatory behavior are both categorically ordered variables. We used ordered probit analysis to deal with the fact that the respondents' migration intentions and preparatory behavior varied in intensity. The tacit assumption of this method is that people can rank their probability of moving abroad or taking preparatory behavior. In ordered probit analysis an underlying score is estimated as a linear function of the independent variables and a set of threshold points. The probability of observing outcome $i$ corresponds to the probability that the estimated linear score function $S_{\mathrm{j}}=\beta_{1} x_{1 \mathrm{j}}+\beta_{2} x_{2 \mathrm{j}}+\ldots \beta_{\mathrm{k}} x_{\mathrm{kj}}$ plus the random error $u j$, is within the range of threshold points estimated for the outcome: 


$$
\operatorname{Pr}\left(\text { outcome }_{j}=i\right)=\operatorname{Pr}\left(\kappa_{i-1}<\sum_{s=1}^{k} \beta_{s} x_{s j}+u_{j} \leq \kappa_{i}\right)
$$

where the error term $u_{j}$ is assumed to be normally distributed. With ordered probit analysis, the model coefficients $\beta_{1}, \beta_{2}, \ldots \beta_{\mathrm{k}}$ are estimated along with the threshold points $\kappa_{1}, \kappa_{2}, \ldots \kappa_{\mathrm{H}-1}$, where $H$ is the number of possible outcomes. The estimated threshold points guide the interpretation of the estimated coefficients, because they indicate how important a variable (e.g. a character trait of a 'stayer') is for the prediction of the likelihood of moving abroad. For instance, for each observation $j$ one can calculate the score function $\left(S_{\mathrm{j}}\right)$ and the true frequency that individual $j$ will not migrate if $S_{\mathrm{j}}+u_{j} \leq \kappa_{1}$, and that he or she is unsure about the move abroad: $\kappa_{1}<S_{j}+u_{j} \leq \kappa_{2}$, etc. One can therefore predict, based on the estimated coefficients, the likelihood of a particular emigration intention outcome.

Since we over-sampled emigrants in our survey we carried out our multivariate analyses using sample weights that are a function of the dependent variable, the intention to emigrate (Winship and Radbill, 1994). And because weighted estimation of the ordered probit analyses will induce heteroskedasticity in the error terms, we used White-heteroskedastic consistent estimation for the standard errors (White, 1980).

\section{Results}

\subsection{Evaluation of the quality of a nation}

Table 1 presents the results of the principal components analysis of the evaluation of living conditions in the private and public domains of Dutch society. The analysis yields four components with an eigenvalue higher than 1 . The four components explain 59 percent of the variance. Each new variable has been given a name that corresponds to the cluster of items with which it has a strong correlation. Whereas a high loading means that the item is strongly correlated with the component concerned, a low factor loading indicates a weak correlation. Items with a factor loading of 0.50 or more are shown in bold and were used to calculate measures for the four dimensions.

\section{Dimension 1: Welfare state institutions}

Twenty-nine percent of the variance in the evaluation of the home country is related to the first component. Respondents with a high score on this dimension have negative opinions about the Dutch welfare state. They were negative about the level of health care services, the systems of education, 
social security and pensions, and the system of law and order. This dimension of the public domain includes the institutions governing the production of public goods and offering social protection and protection of property rights. The evaluation of this dimension is essentially a grade given for these institutions.

Table 1: Results of a principal components analysis with varimax rotation on 16 items concerning living conditions in the Netherlands $(N=1,489)$

\begin{tabular}{lcccc}
\hline $\begin{array}{l}\text { Evaluation of characteristics } \\
\text { of the home country }\end{array}$ & Factor 1 & Factor 2 & Factor 3 & Factor 4 \\
\hline Welfare state institutions & & & & \\
Health care system & $\mathbf{0 . 8 0}$ & 0.05 & 0.06 & 0.10 \\
Social security & $\mathbf{0 . 8 4}$ & 0.10 & 0.05 & 0.17 \\
Educational services & $\mathbf{0 . 7 5}$ & 0.04 & 0.23 & 0.07 \\
System of law and order & $\mathbf{0 . 6 7}$ & 0.33 & 0.02 & 0.09 \\
Pension system & $\mathbf{0 . 7 7}$ & 0.14 & -0.01 & 0.13 \\
Societal problems & & & & \\
Crime level & 0.19 & $\mathbf{0 . 7 8}$ & 0.04 & 0.05 \\
Pollution level & 0.09 & $\mathbf{0 . 5 5}$ & 0.30 & 0.07 \\
Mentality of the people & 0.26 & $\mathbf{0 . 5 6}$ & 0.18 & 0.07 \\
Ethnic diversity & 0.12 & $\mathbf{0 . 6 7}$ & 0.13 & 0.08 \\
Environmental quality & & & & \\
Nature and space & 0.15 & 0.00 & $\mathbf{0 . 8 2}$ & 0.11 \\
Population density & 0.05 & 0.44 & $\mathbf{0 . 6 5}$ & 0.07 \\
Silence & 0.02 & 0.09 & $\mathbf{0 . 8 3}$ & 0.03 \\
Private living conditions & & & & \\
Housing & 0.11 & -0.10 & 0.27 & $\mathbf{0 . 6 4}$ \\
Income & 0.25 & 0.08 & 0.01 & $\mathbf{0 . 7 2}$ \\
Working conditions & 0.13 & 0.23 & 0.00 & $\mathbf{0 . 7 3}$ \\
Social contacts & 0.11 & -0.02 & 0.12 & $\mathbf{0 . 6 9}$ \\
& & & & \\
Eigenvalue & 4.61 & 1.95 & 1.60 & 1.20 \\
R & 0.29 & 0.12 & 0.10 & 0.08 \\
\hline
\end{tabular}

\section{Dimension 2: Societal problems}

A second dimension, which explains 12 percent of the variance in the items, captures opinions on societal problems. Respondents scoring high on this dimension are negative about the level of crime, pollution, the mentality of the people in general and the level of ethnic diversity. Whereas the first component deals with institutions, the second component encompasses the quality of social interaction and as such reflects to some extent the success or failure of welfare state institutions in dealing with the external effects of human action. Crime, pollution and the degree to which people respect social norms reflects the respect of property rights, which a system of law and order tries to produce. Ethnic diversity may seem like a maverick component among these problems. However, a faltering immigrant 
integration process, reflected by segregation in schools and neighborhoods, is essentially a problem of externalities that may entice people to perceive ethnic diversity negatively.

\section{Dimension 3: Environmental quality}

The third dimension refers to attitudes about the public living conditions in terms of nature and space, silence and population density. Respondents who score high on this dimension evaluate the living conditions in the home country negatively. Ten percent of the variance in the evaluation of the home country was related to this component. This factor relates to the demand for nature, space and silence. These public goods are by their very nature rivalrous and the prominent score of population density in Table 1 indicates how respondents perceive the friction caused by population density. Recent research for the Netherlands shows that the public good 'silence' is valued as a luxury good, i.e. higher income groups show a greater willingness to pay for a reduction in noise (Udo et al., 2006). In other words, silence in a crowded country such as the Netherlands is an important element of the quality of life.

\section{Dimension 4: Private living conditions}

The fourth dimension captures opinions on what can broadly be described as private living conditions. Respondents who score low on this dimension are not satisfied with their income, housing, working conditions and social contacts. Contrary to the public dimensions of the quality of a nation, this element refers exclusively to private elements and is - as expected - almost unrelated to the aspects of the public domain.

Interestingly, the various correlation coefficients show how the evaluations of the public and private dimensions of Dutch society are separated into plausible clusters. Based on the results of the principal component analysis we assessed the reliability of the psychometric properties of the four dimensions by calculating Cronbach's alpha for each dimension including the items with high factor loadings (bold). The computed alphas are 0.85 for welfare state evaluations; 0.67 for societal problems; 0.75 for environmental quality; and 0.68 for private living conditions. High scores on the scales indicate negative evaluations.

Descriptive statistics for all explanatory variables in the models are presented in Table 2, disaggregated by those who have an intention to move abroad ('movers') and those who do not ('stayers'). The statistics are self-explanatory and give us a clue as to which dimensions distinguish potential migrants from the large crowd of non-migrants. 
Table 2: Descriptive statistics of stayers versus potential emigrants

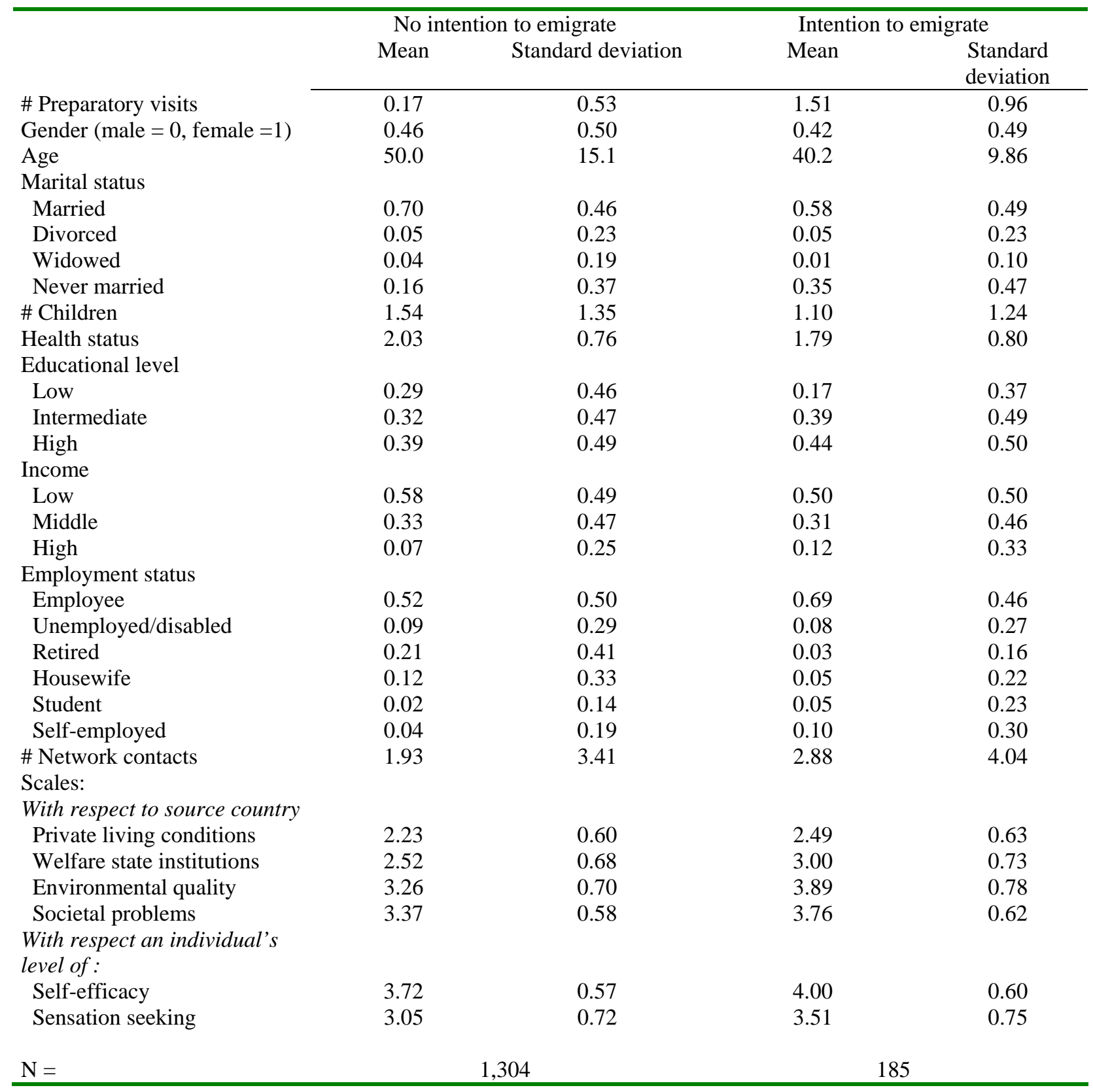

Source: NIDI emigration survey (2005) 


\subsection{Explaining intentions and behavior to emigrate}

The results of the analyses explaining emigration intentions and preparatory behavior are presented in Table 3. Two models are estimated for both emigration intentions and preparatory behavior. The first model includes individual characteristics such as the importance of human capital, social networks and personality traits as determinants of the decision to emigrate. The second model extends the first model by adding an evaluation of the quality of the home country.

Table 3: Ordered probit analyses to explain intentions and preparatory behavior to emigrate $(\mathrm{N}=\mathbf{1 , 4 8 9})$

\begin{tabular}{|c|c|c|c|c|c|c|c|c|}
\hline \multirow[b]{3}{*}{ Human capital } & \multicolumn{4}{|c|}{ Model I } & \multicolumn{4}{|c|}{ Model II } \\
\hline & \multicolumn{2}{|c|}{ Intention } & \multicolumn{2}{|c|}{ Preparatory behavior } & \multicolumn{2}{|c|}{ Intention } & \multicolumn{2}{|c|}{ Preparatory behavior } \\
\hline & Coefficient & t-value & Coefficient & t-value & Coefficient & t-value & Coefficient & t-value \\
\hline Gender $($ male $=0$ ) & $-0.26 * *$ & 3.87 & $-0.24 * *$ & 2.65 & $-0.26 * *$ & 3.82 & $-0.24 * *$ & 2.63 \\
\hline Age & $-0.03^{* *}$ & 9.99 & -0.01 & 1.12 & $-0.03 * *$ & 9.99 & -0.00 & 0.81 \\
\hline Health status & 0.07 & 1.50 & -0.02 & 0.36 & -0.02 & 0.40 & -0.08 & 1.43 \\
\hline \multicolumn{9}{|l|}{ Educational level } \\
\hline Intermediate & 0.12 & 1.40 & 0.20 & 1.76 & 0.14 & 1.60 & $0.24 *$ & 1.98 \\
\hline \multicolumn{9}{|l|}{ Income } \\
\hline Middle & 0.07 & 1.01 & -0.08 & 0.77 & 0.12 & 1.65 & -0.06 & 0.58 \\
\hline High & $0.29 *$ & 2.51 & 0.26 & 1.68 & $0.33^{* *}$ & 2.89 & 0.26 & 1.59 \\
\hline \multicolumn{9}{|l|}{ Employment status } \\
\hline Retired & $-0.37^{* *}$ & 2.86 & 0.09 & 0.59 & $-0.37 * *$ & 2.78 & 0.12 & 0.68 \\
\hline Unemployed/disabled & 0.15 & 1.31 & -0.06 & 0.37 & 0.11 & 0.95 & -0.04 & 0.25 \\
\hline Housewife & -0.13 & 1.02 & 0.28 & 1.74 & -0.16 & 1.30 & 0.27 & 1.57 \\
\hline Self-employed & 0.19 & 1.49 & 0.16 & 0.95 & 0.22 & 1.64 & 0.22 & 1.24 \\
\hline \multicolumn{9}{|l|}{ Social networks } \\
\hline \multicolumn{9}{|l|}{ Marital status } \\
\hline Divorced & $0.44^{* *}$ & 3.11 & 0.18 & 0.96 & $0.47 * *$ & 3.41 & 0.21 & 1.08 \\
\hline Widowed & -0.38 & 1.65 & -0.09 & 0.34 & -0.51 & 1.86 & -0.22 & 0.73 \\
\hline Never married & $0.21 *$ & 2.33 & $0.27 *$ & 2.41 & $0.21 *$ & 2.22 & $0.25 *$ & 2.17 \\
\hline Marital status missing & 0.03 & 0.20 & -0.38 & 1.75 & 0.02 & 0.12 & -0.34 & 1.48 \\
\hline \# Children & -0.04 & 1.50 & -0.04 & 1.00 & -0.00 & 0.16 & -0.02 & 0.63 \\
\hline \# Network contacts & $0.05 * *$ & 5.63 & $0.06 * *$ & 5.74 & $0.05 * *$ & 5.26 & $0.06 * *$ & 5.38 \\
\hline \multicolumn{9}{|l|}{ Personality } \\
\hline Self-efficacy & 0.10 & 1.89 & $0.23 * *$ & 2.88 & $0.18 * *$ & 3.02 & $0.25 * *$ & 2.97 \\
\hline Sensation seeking & $0.29 * *$ & 6.50 & $0.34 * *$ & 6.07 & $0.24 * *$ & 5.05 & $0.29 * *$ & 5.05 \\
\hline \multicolumn{9}{|l|}{ Evaluation private domain } \\
\hline Private living conditions & - & - & - & - & 0.12 & 1.78 & 0.05 & 0.74 \\
\hline \multicolumn{9}{|l|}{ Evaluation public domain } \\
\hline Welfare state institutions & - & - & - & - & $0.23 * *$ & 4.10 & 0.08 & 1.18 \\
\hline Pseudo $R^{2}$ & \multicolumn{2}{|c|}{0.15} & \multicolumn{2}{|c|}{0.09} & \multicolumn{2}{|c|}{0.20} & \multicolumn{2}{|c|}{0.12} \\
\hline
\end{tabular}

${ }^{*} \mathrm{p}<0.05 ; * * \mathrm{p}<0.01$, cut-off points have been suppressed in the presentation of results. 
The first model shows that the three elements of migration theory - human capital, social networks and psychological dispositions - influence the intention to emigrate. People with firm intentions to emigrate are generally male, young, higher educated, well off in terms of income and not married. The fact that retired respondents are less likely to emigrate may strike some as odd as migration is often depicted as a likely goal of retirement. ${ }^{8}$ Also the size of a social network abroad increases the likelihood of emigration considerably: the larger the social network, consisting of family and friends who have already emigrated, the higher the probability of leaving. Whereas divorcees show a much greater tendency to emigrate, widow(er)s are more averse to emigration.

In addition to the traditional elements, we found strong effects of self-efficacy and sensation seeking in explaining preparatory actions. Individuals who score high in terms of self-efficacy and sensation seeking show more involvement in preparatory behavior than those who lack self-efficacy or who are averse to new risks or sensations. In explaining emigration intentions it turns out that sensation seeking plays a significant role, whereas self-efficacy shows much weaker results.

In our second model we have included the perceived quality of the public and private domains. In both models the explained variance increases significantly: from 15 to 20 percent for the intention to emigrate and from 9 to 12 percent for preparatory behavior. Two aspects of the public domain are important with respect to the intention to emigrate. The effect of peoples’ opinions regarding environmental pressures (lack of space, silence, population density) was found to be particularly important. In addition, negative evaluations of the welfare state are firmly associated with a greater intention to emigrate. Concerns about current societal problems - such as crime, pollution and ethnic diversity - are not statistically significant for emigration intentions, but of some significance in predicting preparatory behavior. In other words, a faltering welfare state may perhaps trigger the desire to emigrate, but societal problems actually translate the desires into action. Interaction effects were tested in line with standard regression procedures. Priority was given to interaction effects of the evaluation of public goods with age, education, gender and income. None of the interaction terms were significant, except that the effect of the evaluation of the welfare state on emigration intentions and preparatory behavior was somewhat stronger for the high-income groups. The interaction terms have not been included in Table 3 because they were neither large nor did they add significant explanatory power to model II,

\footnotetext{
${ }^{8}$ There are two plausible explanations for the absence of strong retirement migration effects. One is the fact that social ties with children and grandchildren is so strong that most would not want to move abroad. A second explanation is that the character of elderly migration falls outside the common definition of permanent emigration. Someone is considered an emigrant if he or she intends to remain outside the Netherlands for more than eight months and pensioners apparently do not move abroad permanently. When they do move abroad it is mostly for several months to a second home or apartment, primarily in France or Spain.
} 
In the appendix to this article, the marginal effects have been calculated to provide quantitative insight into the importance of the coefficients for each outcome. To gain some additional insight into the importance of the various dimensions of the public domain in explaining emigration intentions, we carried out a counterfactual analysis. We calculated the probability of emigration under different assumptions of the respondents' evaluations of the home country and compared these results with our baseline scenario as represented in model II. First, we estimated emigration probabilities based on model II in Table 4. Second, we estimated emigration probabilities based on extremely negative evaluations of the quality of living in the Netherlands, as approximated by the private living conditions and the three dimensions of the public domain. The emigration probabilities can be reestimated by imputing the highest score values for the various dimensions and employing the estimated coefficients of Model II.

Table 4: Counterfactual simulations of extreme negative evaluation of home country

\begin{tabular}{lccc}
\hline & \multicolumn{2}{c}{ Intention to emigrate (percentages) } \\
\hline & Probable & Very probable & Total \\
Model II baseline & 2.3 & 2.0 & 4.3 \\
Extreme negative evaluation & & & \\
with respect to: & & & 6.9 \\
1. Private living conditions & 3.9 & 3.0 & 8.9 \\
2. Welfare state institutions & 5.1 & 3.8 & 5.0 \\
3. Societal problems & 2.7 & 2.3 & 9.6 \\
4. Environmental quality & 5.4 & 4.2 & 21.5 \\
5. Public domain $(2+3+4)$ & 13.7 & 7.8 & \\
\hline
\end{tabular}

Table 4 shows that under extremely negative evaluations of the public domain approximately 20 percent of the Dutch population would be inclined to leave the country: 13.7 would probably emigrate and 7.8 percent are very certain about their intention to emigrate. These results underscore the effect of environmental quality in the decision to emigrate. Under extremely negative evaluations of environmental quality, approximately 10 percent would consider the option to emigrate. In short, a perception of severe neglect of the public domain could increase emigration rates by a factor 4 to 5 .

\subsection{Expected conditions in destination countries}

The results suggest that modern-day emigrants are driven out of their home country by a neglect of the quality of the public domain and that they long for what the Dutch consider the Good Life: nature, 
space and a less populated country. The question is, of course, which elements of the public and private domains of life will improve or worsen once they have moved abroad? For the entire sample, the question of improvement is less relevant as 'stayers' will generally not have formed any expectations about life abroad. Expectations of destination countries are a more relevant statistic only for those who intend to move, and this is presented in Table $5 .{ }^{9}$ The table shows how potential emigrants evaluate the characteristics of their preferred country of destination. To offer a benchmark, we have also added the respondents' evaluations of their home country. Ideally, the preferred destination should be everything that the home country is not. But we expect that emigrants will face trade-offs in moving abroad and a priori it is unclear which elements of the private and public domains of life are sacrificed to attain the Good Life abroad.

Table 5: Expected living conditions in preferred country of destination $(\mathrm{N}=146)$

\begin{tabular}{|c|c|c|c|c|c|}
\hline \multirow[t]{2}{*}{$\begin{array}{l}\text { Dimensions of the quality of } \\
\text { nations }\end{array}$} & \multirow{2}{*}{$\begin{array}{c}\begin{array}{c}\text { Evaluation } \\
\text { home country }\end{array} \\
\% \text { Negative } \\
{ }^{\mathbf{a}}\end{array}$} & \multicolumn{4}{|c|}{$\begin{array}{c}\text { Expectations of living conditions in preferred country } \\
\text { of destination: }\end{array}$} \\
\hline & & (Much) better & The same & (Much) worse & Total \\
\hline Health care system & 27 & 32 & 60 & 9 & 100 \\
\hline Social security & 33 & 16 & 47 & 37 & 100 \\
\hline Educational services & 24 & 35 & 51 & 14 & 100 \\
\hline Law and order & 44 & 41 & 46 & 13 & 100 \\
\hline Pension system & 35 & 15 & 51 & 34 & 100 \\
\hline Societal problems & & & & & \\
\hline Crime level & 73 & 61 & 34 & 5 & 100 \\
\hline Pollution & 62 & 66 & 29 & 5 & 100 \\
\hline Mentality of the people & 79 & 90 & 9 & 1 & 100 \\
\hline Ethnic diversity & 50 & 58 & 39 & 3 & 100 \\
\hline Environmental quality & & & & & \\
\hline Nature and space & 57 & 98 & 2 & 0 & 100 \\
\hline Population density & 84 & 91 & 6 & 3 & 100 \\
\hline Silence & 71 & 91 & 8 & 1 & 100 \\
\hline Private living conditions & & & & & \\
\hline Housing & 11 & 63 & 28 & 9 & 100 \\
\hline Income & 13 & 17 & 50 & 33 & 100 \\
\hline Working conditions & 33 & 62 & 30 & 8 & 100 \\
\hline Social contacts & 6 & 38 & 52 & 10 & 100 \\
\hline
\end{tabular}

(a) In this column the evaluations 'negative' and 'very negative' are grouped together.

\footnotetext{
${ }^{9}$ The number of potential migrants is smaller than in Table 2 because the list of questions about expected living conditions in the preferred country of destination was not put to respondents of the nation-wide sample but only to the visitors to the Expats fair. Only visitors who expressed a clear intention to emigrate are included in the Table 5; the other respondents were still uncertain about their emigration intentions.
} 
Table 5 is more or less the mirror image of peoples' evaluations of their home country. Interestingly, aspects that are expected to be (much) worse in the preferred or expected country of destination are related to financial security: one third of the respondents who intend to emigrate expect that their income will drop, and the social security and pension systems will be of lesser quality than the Dutch systems. More than ninety percent of the potential emigrants expect that the countries of destination will offer a significantly higher environmental quality, and judging from the second column of Table 5 this dimension is felt to be most neglected in the Netherlands: 84 percent of the Dutch find population density a negative aspect of living in their country. A majority also expect a decrease in societal problems in their preferred country in terms of pollution, crime level and the mentality of the people. Each of these elements is also evaluated negatively for the Netherlands.

\section{Conclusion and discussion}

Understanding the causes of international migration is of growing importance in a globalizing world. Geographically dispersed spheres and markets are becoming increasingly integrated either by flows of goods and services or by flows or capital and labor. Whereas many studies focus on migration from less developed countries to the more developed countries (Hatton and Williamson 2003, 2004; and Van Dalen et al. 2005), only relatively few studies address emigration from these high-income countries. In this study we have focused on the Netherlands to answer the question why people intend to emigrate. Based on data about intentions and preparatory behavior we found that age, education, income and social networks play an important role in triggering emigration. The potential migrant is predominantly young, better educated with a high income and with family or friends abroad. The effects of social networks - both the networks abroad and the networks at home (as approximated by marital status) - are substantial, although we cannot pinpoint exactly why the network exerts such a strong effect on emigration intentions. All in all, the results suggest that economic considerations play a role in explaining emigration from the Netherlands, but relying solely on economic mechanisms explains only part of the emigration flow. As such the results are in line with observations made by Hatton (2004) for emigration from the UK during the twentieth century: economic considerations still matter today, but they are much less important than they were before the Second World War.

The economic theory of migration is therefore a good starting point but it is not sufficient for an understanding of emigration. To understand fully why some people want to leave while others stay we have introduced two novel elements in migration research. First we found that, in addition to the traditional elements, personality characteristics - as approximated by the level of sensation seeking and 
self-efficacy - are important predictors of emigration intentions. The emigration process - the act of moving from one country to another - is partly an activity that generates welfare (read: new sensations). The level of self-efficacy or people's confidence in their ability to deal with changes and unfamiliar situations does not generate welfare but is of importance in effectuating plans. The sensation seeking qualities of a potential migrant should be interpreted with care, however. Sensation seeking is a double-sided personality trait and need not be connected with creative talent. It can also entice individuals to make decisions they might regret in later life. As Horvath and Zuckerman (1993) make clear, this personality trait may also be connected with criminal behavior, for example, or drunken driving or unsafe sex. It is important to note that a high level of sensation seeking does not equal success abroad. Moreover, this personality trait may also contribute to an understanding of return migration or repeat migration.

The second novelty is connected with the explicit incorporation of the public domain in models of international migration. Migration theory traditionally refers to the importance of the private domain (income, housing, work and social networks). We show, however, that the public domain is of significance in triggering emigration. Such a mechanism has been acknowledged to be relevant for internal migration. A major finding in our analysis is that this force has quite some relevance in explaining international migration. In the eyes of the Dutch, the public domain refers to: (1) societal problems such as crime, pollution or ethnic diversity, which generally have resulted in some form of collective action; (2) elements that affect the quality of the environment, such as nature and space, silence, and population density; and lastly (3) welfare state institutions that deal with societal problems, i.e. the quality of the educational system, social security, health care, law and order, and oldage pensions. The quality of the environment is shown to be a particularly important driving force influencing the emigration intentions of the Dutch. This finding may underscore Hunter's plea (2005) to examine the relationship between migration and environmental hazards and is particularly interesting in light of the claim made by the National Research Council that "there is very little empirical documentation of the relationships between migration and the environment.” (1999: 57).

The quality of the public domain is of key importance in understanding today's emigration from the Netherlands. It is hard to say to what extent we can generalize these results to other highincome countries. Concern about the quality of government institutions in the provision of public goods ranks high among citizens in many European countries, as well as in the United States ${ }^{10}$ and on that count alone one can expect this force to be relevant in most western countries. With regard to the

\footnotetext{
${ }^{10}$ See, for example, for the opinions of Europeans the (standard) Eurobarometers on the state of the European Union: http://europa.eu.int/comm/public_opinion/archives/eb/eb63/eb63_en.pdf, and for the United States: NPR-Kaiser-Kennedy School Poll on Attitudes Toward Government: http://www.npr.org/programs/specials/poll/govt/gov.toplines.pdf
} 
importance of factors related to population density one could argue that the Netherlands is an exceptional case since it is one of the most crowded and urbanized nations in the world (Van Dalen and Henkens, 2005). Actual population density may not be such a strong predictor of feelings of overcrowdedness. In the 1950s, for instance, the question of overpopulation was seen as one of the most pressing problems of Dutch society, whereas the country's population size at that time totaled 10 million inhabitants. Today, the level of overcrowding is again perceived as a serious problem, but this time the population of the Netherlands numbers 16 million, which seems to suggest that people adapt to certain density levels. Crowdedness may become a problem when rules and regulations by the state malfunction and as such it is a problem for any nation or region that is highly urbanized.

We would like to close with a point of common concern among policy makers in many technologically advanced countries: the emigration of their most talented inhabitants (cf. OECD, 2005). The concern about the so-called 'brain drain' may be justified as it can undermine the competitiveness of countries. Technologically advanced sectors of the economy often depend strongly on highly skilled individuals. The importance of geographically clustered centers of excellence will undoubtedly remain of importance as technologically advanced knowledge is often complex and of a tacit nature. The United States has mostly been at the receiving end of the talent flow, but according to Florida’s (2005) account it may also plague the United States. The central concern of most governments is how to remain an attractive haven for the brains of a nation. Our research suggests that money does not matter that much to today's potential emigrants. Moving to the preferred country of destination is even expected to be associated with a substantial fall in income by approximately one third of the potential migrants. The policy implications of that observation can be far-reaching for the brain drain debate. De Voretz and Iturralde (1999), for example, suggest a labor tax/subsidy scheme to keep highly educated Canadians from moving to the United States. The tacit assumption is that emigrants are sensitive to wage differences. And when financial incentives are of no great value in the decision making process of potential emigrants, tax proposals of this kind are deemed to have little effect on emigration flows. What really matters is the quality of the public domain and the fact that those who intend to move are implicitly casting a vote of no confidence. By choosing the 'exit' option and foregoing the option of 'voice' (cf. Hirschman, 1970) fiscal competition is no longer restricted to local governments but is increasingly also becoming an affair between national governments. And that specific observation may perhaps be the true sign that we are currently living in the age of globalization. 


\section{Appendix: Quantification of marginal effects}

The estimated parameters based on the ordered probit model do not give the reader an idea of how big the reactions really are with respect to various changes in the explanatory variables. To gain an insight into the quantitative importance of coefficients, one can calculate the marginal effects per outcome category and in a way mimic a probit model for each separate outcome. In Tables A1 and A2 the marginal effects are estimated that correspond to model II in Table 3.

Table A1: Marginal effects of ordered probit analysis of emigration intentions ${ }^{a}$

\begin{tabular}{|c|c|c|c|c|c|}
\hline & $\begin{array}{c}\text { No intention at } \\
\text { all }\end{array}$ & No, probably not & $\begin{array}{c}\text { Outcome }= \\
\text { Maybe }\end{array}$ & Yes, probably & $\begin{array}{l}\text { Yes, very } \\
\text { probably }\end{array}$ \\
\hline Probability & 0.566 & 0.351 & 0.077 & 0.004 & 0.002 \\
\hline \multicolumn{6}{|l|}{ Human capital } \\
\hline Gender (male $=0$ ) & $0.103^{* *}$ & $-0.062 * *$ & $-0.035 * *$ & $-0.003^{* *}$ & $-0.002 * *$ \\
\hline Age & $0.014 * *$ & $-0.008 * *$ & $-0.005 * *$ & $-0.000 * *$ & $-0.000 * *$ \\
\hline Health status & 0.007 & -0.005 & -0.003 & -0.000 & -0.000 \\
\hline \multicolumn{6}{|l|}{ Educational level } \\
\hline Intermediate & -0.055 & 0.033 & 0.019 & 0.002 & 0.001 \\
\hline High & $-0.121 * *$ & $0.072 * *$ & $0.044 * *$ & $0.004 * *$ & $0.002^{*}$ \\
\hline \multicolumn{6}{|l|}{ Income } \\
\hline Middle & -0.048 & 0.029 & 0.017 & 0.001 & 0.001 \\
\hline High & $-0.129 * *$ & $0.069 * *$ & $0.052 *$ & $0.005^{*}$ & $0.003^{*}$ \\
\hline \multicolumn{6}{|l|}{ Employment status } \\
\hline Retired & $0.143^{* *}$ & $-0.094 * *$ & $-0.044 * *$ & $-0.003 * *$ & $-0.002 * *$ \\
\hline Unemployed/disabled & -0.045 & 0.027 & 0.016 & 0.001 & 0.001 \\
\hline Housewife & 0.063 & -0.040 & -0.020 & -0.002 & -0.001 \\
\hline Student & -0.070 & $0.040 *$ & 0.027 & 0.002 & 0.002 \\
\hline Self-employed & -0.089 & 0.050 & 0.034 & 0.003 & 0.002 \\
\hline \multicolumn{6}{|l|}{ Social networks } \\
\hline \multicolumn{6}{|l|}{ Marital status } \\
\hline Divorced & $-0.187 * *$ & $0.092 * *$ & $0.081 * *$ & $0.008 *$ & $0.005^{*}$ \\
\hline Widowed & $0.185 *$ & -0.130 & $-0.050 * *$ & $-0.003 * *$ & $-0.002 * *$ \\
\hline Never married & $-0.083^{*}$ & $0.048 *$ & $0.031 *$ & 0.003 & 0.002 \\
\hline Marital status missing & -0.008 & 0.005 & 0.003 & 0.000 & 0.000 \\
\hline \# Children & 0.002 & -0.001 & -0.001 & -0.000 & -0.000 \\
\hline \# Network contacts & $-0.018 * *$ & $0.011^{* *}$ & $0.006 * *$ & $0.001^{* *}$ & $0.001^{* *}$ \\
\hline \multicolumn{6}{|l|}{ Personality } \\
\hline Self efficacy & $-0.070 * *$ & $0.043 * *$ & $0.024 * *$ & $0.002 * *$ & $0.001 * *$ \\
\hline Sensation seeking & $-0.093 * *$ & $0.057 * *$ & $0.032 * *$ & $0.003 * *$ & $0.001 * *$ \\
\hline \multicolumn{6}{|l|}{ Evaluation private domain } \\
\hline Private living conditions & -0.048 & 0.030 & 0.017 & 0.001 & 0.001 \\
\hline \multicolumn{6}{|l|}{ Evaluation public domain } \\
\hline Societal problems & -0.029 & 0.018 & 0.010 & 0.001 & 0.000 \\
\hline Environmental quality & $-0.160 * *$ & $0.098 * *$ & $0.055^{* *}$ & $0.004 * *$ & $0.002 * *$ \\
\hline Welfare state institutions & $-0.090 * *$ & $0.055^{* *}$ & $0.031 * *$ & $0.002 * *$ & $0.001^{* *}$ \\
\hline
\end{tabular}

(a) ** significance at $<0.01$, * significance at $<0.05$. For dummy variables the marginal effects constitute the effect of a discrete change of a dummy variable from 0 to 1 . Calculated probabilities are evaluated at mean values of the explanatory variables. 
Table A2: Marginal effects of ordered probit analysis of emigration preparatory behavior ${ }^{\mathrm{a}}$

\begin{tabular}{|c|c|c|c|c|}
\hline \multirow[b]{3}{*}{ Probability } & \multicolumn{4}{|c|}{ Outcome = } \\
\hline & No action & 1 visit & 2 visits & 3 visits \\
\hline & 0.904 & 0.066 & 0.024 & 0.006 \\
\hline \multicolumn{5}{|l|}{ Human capital } \\
\hline Gender (male $=0$ ) & $0.042 * *$ & $-0.025 * *$ & $-0.013 *$ & $-0.004^{*}$ \\
\hline Age & 0.001 & -0.000 & -0.000 & -0.000 \\
\hline Health status & 0.014 & -0.008 & -0.004 & -0.001 \\
\hline \multicolumn{5}{|l|}{ Educational level } \\
\hline Intermediate & -0.042 & 0.025 & 0.013 & 0.004 \\
\hline High & -0.038 & 0.023 & 0.012 & 0.004 \\
\hline \multicolumn{5}{|l|}{ Income } \\
\hline Middle & 0.010 & -0.006 & -0.003 & -0.001 \\
\hline High & -0.050 & 0.029 & 0.016 & 0.006 \\
\hline \multicolumn{5}{|l|}{ Employment status } \\
\hline Retired & -0.021 & 0.012 & 0.006 & 0.002 \\
\hline Unemployed/disabled & 0.007 & -0.004 & -0.002 & -0.001 \\
\hline Housewife & -0.052 & 0.030 & 0.016 & 0.006 \\
\hline Student & 0.017 & -0.010 & -0.005 & -0.001 \\
\hline Self-employed & -0.043 & 0.025 & 0.014 & 0.005 \\
\hline \multicolumn{5}{|l|}{ Social networks } \\
\hline \multicolumn{5}{|l|}{ Marital status } \\
\hline Divorced & -0.039 & 0.023 & 0.012 & 0.004 \\
\hline Widowed & 0.033 & -0.020 & -0.009 & -0.003 \\
\hline Never married & $-0.048 *$ & $0.028 *$ & 0.015 & 0.005 \\
\hline Marital status missing & 0.047 & -0.030 & -0.013 & -0.004 \\
\hline \# Children & 0.004 & -0.002 & -0.001 & -0.000 \\
\hline \# Network contacts & $-0.010 * *$ & $0.006^{* *}$ & $0.003^{* *}$ & $0.001 * *$ \\
\hline \multicolumn{5}{|l|}{ Personality } \\
\hline Self efficacy & $-0.043^{* *}$ & $0.026^{* *}$ & $0.013^{* *}$ & $0.004 * *$ \\
\hline Sensation seeking & $-0.050 * *$ & $0.030 * *$ & $0.015^{* *}$ & $0.005^{* *}$ \\
\hline \multicolumn{5}{|l|}{ Evaluation private domain } \\
\hline Private living conditions & $-0.009 *$ & 0.005 & 0.003 & 0.001 \\
\hline \multicolumn{5}{|l|}{ Evaluation public domain } \\
\hline Societal problems & $-0.049 * *$ & $0.030 * *$ & $0.015^{* *}$ & $0.005^{* *}$ \\
\hline Environmental quality & $-0.045 * *$ & $0.027 * *$ & $0.014 * *$ & $0.004 * *$ \\
\hline Welfare state institutions & -0.014 & 0.008 & 0.004 & 0.001 \\
\hline
\end{tabular}

(a) The preparatory behavior refers to consulting three different institutions in preparation of a possible move abroad. ** significance at $<0.01$, * significance at $<0.05$. For dummy variables the marginal effects constitute the effect of a discrete change of a dummy variable from 0 to 1 . Calculated probabilities are evaluated at mean values of the explanatory variables. 


\section{References}

Abrams, D., S. Hinkle, and M. Tomlins, 1999, Leaving Hong Kong: The Roles of Attitude, Subjective Norm, Perceived Control, Social Identity and Relative Deprivation, International Journal of Intercultural Relations, 23: 319-338.

Bandura, A., 1982, Self-Efficacy Mechanism in Human Agency, American Psychologist, 37: 122-147.

Becker, S.O., A. Ichino, and G. Peri, 2003, How Large is the ‘Brain Drain’ from Italy?, CESIFO Working paper no. 839, Munich.

Berry, J.W., 2001, A Psychology of Immigration, Journal of Social Issues, 57: 615-631.

Boeri, T., G. Hanson, and B. McCormick (eds.), 2002, Immigration Policy and the Welfare System, Oxford University Press, Oxford.

Boneva, B.S., and I.H. Frieze, 2001, Toward a Concept of Migrant Personality, Journal of Social Issues, 57: 477-491.

Boneva, B., I.H. Frieze, A. Ferligoj, E. Jarosova, D. Pauknerova, and A. Orgocka, 1998, Achievement, Power, and Affiliation Motives as Clues to (E)migration Desires: A Four-Countries Comparison, European Psychologist, 3: 247-254.

Borjas, G.J., 1987, Self-Selection and the Earnings of Immigrants. American Economic Review 77: 531-553

Borjas, G.J., 1991, Immigration and Self-Selection, in: J. Abowd, and R. Freeman (eds.) Immigration, Trade and the Labor Market, University of Chicago Press, Chicago, pp. 29-76.

Borjas, G.J., and B. Bratsberg, 1996, Who Leaves? The Outmigration of the Foreign-Born, Review of Economics and Statistics, 78: 165-176.

Bosscher, R.J., and J.H. Smit, 1998, Confirmatory Factor Analysis of the General Self-Efficacy Scale, Behaviour Research and Therapy, 36: 339-343.

Burda, M.C., W. Härdle, M. Müller, and A. Werwartz, 1998, Semiparametric Analysis of German East-West Migration Intentions: Facts and Theory. Journal of Applied Econometrics 13: 525541

Chiswick, B.R., 1999, Are Immigrants Favorably Self-Selected? American Economic Review, Papers and Proceedings 89: 181-185.

Chiswick, B.R., and T.J. Hatton, 2002, International Migration and the Integration of Labor Markets, IZA Discussion Paper, no. 559, Bonn.

Clark, X., T.J. Hatton and J.G. Williamson, 2004, What Explains Emigration Out of Latin America?, World Development, 32: 1871-1890.

Coase, R.H., 1960, The Problem of Social Cost, Journal of Law and Economics, 1: 1-44. 
De Jong, G.F., and J.T. Fawcett, 1981, Motivations for Migration: An Assessment and a ValueExpectancy Research Model, in: G.F. de Jong and R.W. Gardner (eds.), Migration Decision Making, Pergamon Press, New York, pp. 90-129.

De Jong, G.F., 2000, Expectations, Gender, and Norms in Migration Decision-Making, Population Studies, 54: 307-319.

DeVoretz, D.J., and C. Iturralde, 2001, Why Do High Skilled Canadians Stay in Canada?, Policy Options, March 2001 issue: 59-63.

Dunteman, G.H., 1989, Principal Components Analysis, Series: Quantitative Applications in the Social Sciences, Sage publications, Newbury Park, London, New Delhi.

Epstein, G.S., and I. Gang, 2004, The Influence of Others on Migration Plans, CEPR Discussion Paper no. 4617, London.

Eurostat, 2005, Migration Remains the Major Component of Population Growth in the EU, Statistics in Focus, Population and Social Conditions, XX/2005: 1-3.

Florida, R., 2005, The Flight of the Creative Class: The New Global Competition for Talent, Harper Collins, New York.

Frieze, I.H. et al., 2004, Psychological Differences in Stayers and Leavers: Emigration Desires in Central and Eastern European University Students, European Psychologist, 9: 15-23.

Hatton, T.J., 2004, Emigration from the UK, 1870-1913 and 1950-1998, European Review of Economic History, 8: 149-169.

Hatton, T.J., and J.G. Williamson, 1998, The Age of Mass Migration - Causes and Economic Impact, Oxford University Press, Oxford.

Hatton, T.J., and J.G. Williamson, 2004, International Migration in the Long-Run: Positive Selection, Negative Selection and Policy, NBER Working Paper, no. 10529, Cambridge, MA.

Hatton, T.J., and J.G. Williamson, 2005, What Fundamentals Drive World Migration?, in: G.J. Borjas and J. Crisp (eds.), Poverty, International Migration and Asylum, Palgrave MacMillan, New York, pp.15-38.

Hicks, J.R., 1932, The Theory of Wages, MacMillan, London.

Hirschman, A.O., 1970, Exit, Voice and Loyalty - Responses to Decline in Firms, Organizations and States, Harvard University Press, Cambridge MA.

Horvath, P., and M. Zuckerman, 1993, Sensation Seeking, Risk Appraisal, and Risky Behavior, Personality and Individual Differences, 14: 41-52.

Hugo, G., D. Rudd and K. Harris, 2001, Emigration from Australia - Economic Implications, CEDA Information Report no. 77, Committee for Economic Development of Australia.

Hunter, L.M., 2005, Migration and Environmental Hazards, Population \& Environment, 26: 273-302. 
Iqbal, M., 2000, Brain Drain: Empirical Evidence of Emigration of Canadian Professionals to the United States, Canadian Tax Journal, 48: 674-688.

Isaac, J., and C.A. van den Beld, 1953, The Effect of European Migration on the Economy of Sending and Receiving Countries, Interim Report by the Research Group for European Migration Problems, The Hague.

Katz, E., and O. Stark, 1987, International Migration Under Asymmetric Information, Economic Journal, 97: 718-726.

Kaul, I, and R.U. Mendoza, 2004, Advancing the Concept of Public Goods, in: I. Kaul, P. Conceicao, K. Le Goulven, and R.U. Mendoza (eds.), Providing Global Public Goods - Managing Globalization, Oxford University Press, Oxford, pp. 78-111.

Knapp, T.A., and P.E. Graves, 1989, On the Role of Amenities in Models of Migration and Regional Development, Journal of Regional Science, 29: 71-87.

Lam, K.-C., 2002, Interaction Between Economic and Political Factors in the Migration Decision, Journal of Comparative Economics, 30: 488-504.

Massey, D.S., 1999, Why Does Immigration Occur?, in: C. Hirschman, P. Kasinitz and J. DeWind (eds.), The Handbook of International Migration: The American Experience, Russell Sage Foundation, New York, pp. 34-52.

National Research Council, 1999, Human Dimensions of Global Environmental Change: Research Pathways for the Next Decade, National Academies Press, Washington DC.

OECD, 2005, Trends in International Migration, Annual Report 2004, OECD, Paris.

Pedersen, P.J., M. Røed, and L. Schröder, 2003, Emigration from the Scandinavian Welfare States, in: T.M. Andersen and P. Molander (eds.), Alternatives for Welfare Policy, Cambridge University Press, Cambridge, pp.76-104.

Petersen, W., 1952, Some Factors Influencing Postwar Emigration from the Netherlands, Martinus Nijhoff, The Hague.

Petersen, W., 1955, Planned Migration - The Social Determinants of the Dutch-Canadian Movement, University of California Press, Berkeley, LA.

Pfaff, S. and H. Kim, 2003, Exit-Voice Dynamics in Collective Action: An Analysis of Emigration and Protest in the East German Revolution, American Journal of Sociology, 109: 401-404.

Rosen, S., 1974, Hedonic Prices and Implicit Markets: Product Differentiation in Pure Competition, Journal of Political Economy, 82: 34-55.

Sherer, M., J.E. Maddux, B. Mercandante, S. Prentice-Dunn, B. Jacobs, and R.W. Rogers, 1982, The Self-Efficacy Scale: Construction and Validation. Psychological Reports, 51: 663-671. 
Sjaastad, L. A., 1962, The Costs and Returns of Human Migration, Journal of Political Economy 70: 80-93.

Stark, O. and D. E. Bloom, 1985, The New Economics of Labor Migration, American Economic Review, 75: 191-196.

Swierenga, R.P., 2000, Faith and Family - Dutch Immigration and Settlement in the United States, 1820-1920, Holmes \& Meier, New York.

Tiebout, C.M., 1956, A Pure Theory of Local Expenditures, Journal of Political Economy, 64: 416424.

Todaro, M. P., 1969, A Model of Labor Migration and Urban Unemployment in Less Developed Countries, American Economic Review 59: 139-148.

Udo, J., L.H.J.M. Janssen, and S. Kruitwagen, 2006, Stilte heeft zijn 'prijs’ ('Silence has its price’), Economisch Statistische Berichten, 83: 14-16.

Van Dalen, H.P., and K. Henkens, 2005, The Rationality Behind Immigration Policy Preferences, De Economist, 153: 67-83.

Van Dalen, H. P., G. Groenewold, and J. J. Schoorl, 2005, Out of Africa: What Drives the Pressure to Emigrate?, Journal of Population Economics, 18: 741-778.

Watters, J.K., and P. Biernacki, 1989, Targeted Sampling: Options for the Study of Hidden Populations, Social Problems, 36: 416-430

White, H., 1980, A Heteroskedasticity-Consistent Covariance Matrix Estimator and a Direct Test for Heteroskedasticity, Econometrica, 48: 817-830.

Winship, C., and L. Radbill, 1994, Sampling Weights and Regression Analysis, Sociological Methods \& Research, 23: 230-257.

Woodrow-Lafield, K.A., 1996, Emigration from the USA: Multiplicity survey evidence, Population Research and Policy Review, 15: 171-199.

Zuckerman, M., 1971, Dimensions of Sensation Seeking, Journal of Consulting and Clinical Psychology, 36: 45-52. 